\title{
Influence of acetaminophen and trichloroethylene on liver cytochrome P450-dependent monooxygenase system $^{\star \star}$
}

\author{
Andrzej Plewka ${ }^{1 凶}$, Barbara Zielińska-Psuja ${ }^{2}$, Joanna Kowalówka-Zawieja ${ }^{2}$, Grażyna \\ Nowaczyk-Dura $^{1}$, Danuta Plewka ${ }^{1}$, Anna Wiaderkiewicz ${ }^{1}$, Marcin Kamiński ${ }^{1}$ and \\ Jerzy Orłowski ${ }^{2}$ \\ ${ }^{1}$ Department of Histology and Embryology, Silesian School of Medicine, Katowice-Ligota, Poland; \\ ${ }^{2}$ Department of Toxicology, Karol Marcinkowski University of Medical Sciences, Poznań, Poland
}

Received: 23 August, 2000; revised: 7 November, 2000; accepted: 28 November, 2000

Key words: acetaminophen, trichloroethylene, cytochrome P450, glutathione, liver, rat

The aim of the study was to evaluate the effect of acetaminophen (APAP) and/or trichloroethylene (TRI) on the liver cytochrome P450-dependent monooxygenase system, CYP2E1 and CYP1A2 (two important P450 isoforms), and liver glutathione (GSH) content in rats.

Rats were given three different doses of APAP (250, 500 and $1000 \mathrm{mg} / \mathrm{kg} \mathrm{b...)} \mathrm{and}$ then the above-mentioned parameters were measured for $48 \mathrm{~h}$. The lowest APAP dose produced small changes in the cytochrome $P 450$ content of liver. At $500 \mathrm{mg} / \mathrm{kg}$ APAP increased the cytochrome $\mathbf{P} 450$ content to $230 \%$ of the control. The inductive effect was seen at $1000 \mathrm{mg} / \mathrm{kg}$ dose but at $24 \mathrm{~h}$ and later. NADPH-cytochrome P450 reductase activity was the highest after the lowest dose of APAP, while after the highest dose it was equal to the control value.

TRI increased both the cytochrome P450 content and the NADPH-cytochrome P450 reductase activity. When TRI was combined with APAP, both these parameters increased in the first hours of observation, but they returned to the control values at $24 \mathrm{~h}$.

When APAP was given at $250 \mathrm{mg} / \mathrm{kg}$, GSH levels decreased to $55 \%$ of the control at 8 $h$ and returned to the control values at $24 \mathrm{~h}$. The higher doses of APAP decreased GSH levels more than the lowest dose, but after $24 \mathrm{~h}$ GSH levels did not differ from those of the control.

\footnotetext{
${ }^{\star}$ This paper was presented at the Symposium of the Polish Society of Toxicology: "The Metabolism of Drugs and Xenobiotics” held in Bukowina Tatrzańska, 2000.

This study was financially supported in part by the State Committee for Scientific Research (Grant KBN 4P05F 008008).

${ }^{{ }_{T}}$ To whom correspondence should be addressed: Medykow 18, 40-752 Katowice-Ligota, Poland, e-mail: aplewka@infomed.slam.katowice.pl
}

Abbreviations: APAP, acetaminophen, paracetamol; TRI, trichloroethylene; GSH, glutathione; DNTB, 5,5'-dithiobis-(2-nitrobenzoic acid); SDS, sodium dodecyl sulphate. 
When TRI was given at $250 \mathrm{mg} / \mathrm{kg}$, the GSH levels decreased to $68 \%$ of the control at $2 \mathrm{~h}$ and then they increased gradually and tended to exceed the control values at $48 \mathrm{~h}$.

The effect of TRI combined with APAP on the level of GSH was virtually the same as that of APAP alone given at $500 \mathrm{mg} / \mathrm{kg}$.

Acetaminophen (paracetamol, APAP) is an analgesic and antipyretic drug. It is safe at therapeutic doses, but when overdosed, it damages the liver. In the liver APAP is converted by cytochrome P450 to the toxic compound $N$-acetyl-p-benzoquinone imine (Dahlin et al., 1984), which is inactivated by coupling to glutathione (GSH) (Dahlin et al., 1984; Nelson et al., 1990). At higher doses of APAP, the detoxifying capacity of the liver is saturated and APAP metabolites accumulate. APAP hepatotoxicity is therefore closely related to the hepatic level of glutathione (Kuralay et al., 1998).

In the liver, exo- and endogenous compounds are metabolized by the cytochrome P450-dependent monooxygenase system. The enzymes involved in this process are located in the endoplasmic reticulum of the liver, and their activities are dependent on many environmental factors (Plewka \& Bienioszek, 1994; Plewka et al., 1994; Plewka \& Kamiński, 1996; Plewka et al., 1998).

When considering biotransformation processes, it is important to analyze them together with other cellular processes taking place in the hepatocyte. Impairment of these processes may disturb cellular nutrition (Guengerich, 1995; Plewka \& Kamiński, 1996) thus affecting the detoxication reactions (Tamburini \& Schenkman, 1986; Geoptar et al., 1995).

It is well known that glutathione plays an important role in maintaining hepatocyte integrity (Comporti et al., 1991; Amimoto et al., 1995). The availability of this tripeptide for generating complexes with reactive species is often a critical factor for the toxicity of many xenobiotics. It has even been suggested that the level of GSH plays a significant role in determining the detoxifying capacity of the organism (Rikans \& Kasanka, 1984).
Reduced glutathione acts as a reducing factor in the metabolism of many peroxides. This reduction is catalyzed by glutathione peroxidases (Halliwell \& Gutteridge, 1989). A significant decrease in the level of intracellular GSH may lead to oxidative stress. On the other hand, the one-electron reduction of APAP by cytochrome $\mathrm{P} 450$ generates reactive oxygen species, thus leading to excess loss of thiol groups and eventual hepatotoxicity (Moore et al., 1985; Corcoran \& Wong, 1986).

The aim of this study was to evaluate the effect of APAP and/or TRI (Bruckner et al., 1989) on the activity and composition of the cytochrome P450-dependent monooxygenase system and on the GSH content of liver. We wanted to determine whether these two xenobiotics interact with each other, which would increase their hepatotoxic effects, and whether APAP, whose transformation is mediated by cytochrome P450, influences some $\mathrm{P} 450$ isoforms.

\section{MATERIALS AND METHODS}

Materials. All chemicals and reagents used were of analytical grade. The rats were obtained from Animal Husbandry, Department of Toxicology, Karol Marcinkowski University of Medical Sciences (Poznań, Poland).

Experimental procedures. The study was performed in the spring season on adult male Wistar rats weighing approximately $270 \mathrm{~g} \pm$ $10 \%$. The animals were kept under standard conditions (humidity 60\%, temperature $22 \pm$ $2^{\circ} \mathrm{C}, 12 / 12 \mathrm{~h} \mathrm{light/dark}$ cycle) and were fed the standard granulated Murigran chow with access to water ad libitum.

Acetaminophen at a dose of 250,500 or 1000 $\mathrm{mg} / \mathrm{kg}$ b.m., separately or in combination with trichloroethylene at a dose of $250 \mathrm{mg} / \mathrm{kg}$ 
b.m. was given intragastrically by stomach tube in a single application.

The rats were killed by decapitation after 2-, 4-, 8-, 12-, 24-, 36 and $48 \mathrm{~h}$ after drug(s) application.

Liver microsomal fraction was isolated according to Dallner (Dallner, 1974) and content of cytochrome P450 was determined by the method of Estabrook and Werringloer (Estabrook \& Werringloer, 1978). The activity of NADPH-cytochrome P450 reductase was determined by the method of Hodges and Leonard (Hodges \& Leonard, 1974). The amount of cytochrome was expressed in nanomoles of cytochrome per milligram of microsomal protein, whereas the activity of the reductase was expressed in micromoles of reduced cytochrome $c$ per $1 \mathrm{~min}$ for $1 \mathrm{mg}$ of microsomal protein.

The concentration of microsomal protein was measured by the method of Lowry (Lowry et al., 1951) with bovine albumin as a standard.

Glutathione measurement. Total glutathione content (reduced and oxidized) was assayed as decribed by Adams (Adams et al., 1983). Tissue samples (about $50 \mathrm{mg}$ ) were homogenized in $5 \mathrm{ml}$ of $100 \mathrm{mM}$ phosphate buffer, pH 7.5, with $5 \mathrm{mM}$ EDTA (buffer A), which contained $10 \mathrm{mM}$ 5,5'-dithiobis-(2-nitrobenzoic acid) (DNTB). After 10-fold dilution with buffer A, the solution was centrifuged at $2000 \times \boldsymbol{g}$ for $3 \mathrm{~min}$. An aliquot $(0.1$ $\mathrm{ml}$ ) was added to cuvette containing $0.1 \mathrm{ml}$ glutathione disulfide reductase $(0.5 \mathrm{U} / \mathrm{ml})$ (ICN, $120 \mathrm{U} / \mathrm{mg}$ ) in buffer A and $0.1 \mathrm{ml} 5 \mathrm{mM}$ DNTB in buffer A. The reaction was started with the addition of $0.7 \mathrm{ml} 0.3 \mathrm{mM} \mathrm{NADPH}$ and the change of absorbance $(\Delta \mathrm{A})$ was monitored continuously for $6 \mathrm{~min}$ at $412 \mathrm{~nm}$ using a U-3210 spectrophotometer (Hitachi). Reference cuvette contained equal concentrations of DNTB, NADPH, enzyme but no sample. Glutathione content was calculated using the calibration curve representing values of $\Delta \mathrm{A} / 6$ min plotted versus known concentrations of glutathione. The results were expressed in $\mathrm{mg} / \mathrm{g}$ tissue.

Western blot analysis of P450 isoforms. The levels of liver microsome P450 isoforms were measured by Western blot analysis. Microsome protein samples (5 $\mu \mathrm{g}$ of protein) were separated on an $8 \%$ polyacrylamide gel in the presence of SDS as described by Laemmli (1970) After separation, the proteins were transferred onto a PVDF membrane (Millipore) and immunostained. Rabbit antibodies directed to CYP isoforms were purchased from Chemicon Int. Inc. The bound antibodies were probed with a secondary antibody conjugated with alkaline phosphatase and then visualized with BCIP/NBT (Sigma). The blots were scanned and analyzed densitometrically with a One D Scan software (Scanalytics).

Statistical analysis. The results obtained were evaluated statistically. Differences between groups were assessed by one way analysis of variance (ANOVA) followed by KruskalWallis test to compare all groups to a control or Tukey's test to compare each group to every other group.

The results were expressed as the arithmetic mean value of six independent measurements ( $\mathrm{x} \pm$ S.D., $\mathrm{n}=6$ ). The statistically significant differences at $P<0.05$ were marked with a star.

\section{RESULTS}

\section{Cytochrome P450-dependent monooxygenase system}

The $2 \mathrm{~h}$ after acetaminophen administration no changes in cytochrome P450 levels were observed in all examined groups. The lowest dose of this drug elevated slightly contents of this cytochrome at $4 \mathrm{~h}$ and $8 \mathrm{~h}$ and then they decreased to control values. After $48 \mathrm{~h}$ cytochrome P450 level increased again to $115 \%$ of control group (Table 1). 
Table 1. Effects of different doses of acetaminophen and/or trichloroethylene on rat liver cytochrome $\mathbf{P 4 5 0}$ content assayed at different times after treatment.

Cytochrome content is expressed in $\mathrm{nmol} / \mathrm{mg}$ microsomal protein.

\begin{tabular}{cccccc}
\hline & \multicolumn{3}{c}{ Acetaminophen } & TRI & TRI + APAP \\
\cline { 2 - 6 } & $250 \mathrm{mg} / \mathrm{kg}$ & $500 \mathrm{mg} / \mathrm{kg}$ & $1000 \mathrm{mg} / \mathrm{kg}$ & $250 \mathrm{mg} / \mathrm{kg}$ & $250 \mathrm{mg} / \mathrm{kg}+500 \mathrm{mg} / \mathrm{kg}$ \\
\cline { 2 - 6 } Control group & & $0.715 \pm 0.032$ & \\
\hline $2 \mathrm{~h}$ & $0.684 \pm 0.016$ & $0.698 \pm 0.040$ & $0.686 \pm 0.041$ & $0.667 \pm 0.042$ & $0.665 \pm 0.022$ \\
$4 \mathrm{~h}$ & $0.914 \pm 0.078^{*}$ & $1.068 \pm 0.069^{*}$ & $0.665 \pm 0.015$ & $0.489 \pm 0.078^{*}$ & $0.625 \pm 0.045$ \\
$8 \mathrm{~h}$ & $0.847 \pm 0.040^{*}$ & $1.269 \pm 0.214^{*}$ & $0.861 \pm 0.049$ & $0.765 \pm 0.089$ & $0.845 \pm 0.032$ \\
$12 \mathrm{~h}$ & $0.673 \pm 0.037$ & $1.671 \pm 0.107^{*}$ & $0.733 \pm 0.013$ & $0.916 \pm 0.046^{*}$ & $0.986 \pm 0.063^{*}$ \\
$24 \mathrm{~h}$ & $0.654 \pm 0.017$ & $0.895 \pm 0.141^{*}$ & $0.890 \pm 0.014^{*}$ & $1.137 \pm 0.079^{*}$ & $1.091 \pm 0.027^{*}$ \\
$36 \mathrm{~h}$ & $0.742 \pm 0.024$ & $0.942 \pm 0.039^{*}$ & $0.950 \pm 0.028^{*}$ & $0.943 \pm 0.023^{*}$ & $0.687 \pm 0.036$ \\
$48 \mathrm{~h}$ & $0.823 \pm 0.017^{*}$ & $1.089 \pm 0.028^{*}$ & $1.001 \pm 0.040^{*}$ & $0.938 \pm 0.124^{*}$ & $0.720 \pm 0.024$ \\
\hline
\end{tabular}

${ }^{*} P<0.05$ when compared with control.

At the 2-fold higher dose the cytochrome P450 levels were elevated at all groups (without the $2 \mathrm{~h}$ one). The highest APAP dose induced the cytochrome at $24 \mathrm{~h}$ and later. The TRI administration decreased the cytochrome $\mathrm{P} 450$ content at $4 \mathrm{~h}$ only. At $12 \mathrm{~h}$ and later we observed its induction. The highest $\mathrm{P} 450$ levels were seen at $24 \mathrm{~h}$ ( $160 \%$ of control value; Table 1). When given together, TRI and APAP induced the cytochrome at $12 \mathrm{~h}$ and $24 \mathrm{~h}$ only. Later on, this effect quickly disappeared so that P450 level returned to normal at $36 \mathrm{~h}$.
NADPH-cytochrome $\mathrm{P} 450$ reductase activity increased as early as $2 \mathrm{~h}$ after APAP given at $250 \mathrm{mg} / \mathrm{kg}$ (Table 2). At $48 \mathrm{~h}$ the activity was still elevated (no statistically significant diference). When APAP was given at 500 $\mathrm{mg} / \mathrm{kg}$, the induction of this reductase activity at all examined groups was observed (without the $4 \mathrm{~h}$ one). The highest dose of APAP had no effect on NADPH-cytochrome $\mathrm{P} 450$ reductase activity.

TRI increased NADPH-cytochrome P450 reductase activity at $4 \mathrm{~h}$ and at later. When

Table 2. Effects of different doses of acetaminophen and/or trichloroethylene on rat liver NADPHcytochrome $\mathbf{P 4 5 0}$ activity assayed at different times after treatment.

NADPH-cytochrome P450 activity is expressed in micromol/min per $\mathrm{mg}$ microsomal protein.

\begin{tabular}{cccccc}
\hline & \multicolumn{3}{c}{ Acetaminophen } & TRI & TRI + APAP \\
\cline { 2 - 6 } & $250 \mathrm{mg} / \mathrm{kg}$ & $500 \mathrm{mg} / \mathrm{kg}$ & $1000 \mathrm{mg} / \mathrm{kg}$ & $250 \mathrm{mg} / \mathrm{kg}$ & $\begin{array}{c}250 \mathrm{mg} / \mathrm{kg}+ \\
500 \mathrm{mg} / \mathrm{kg}\end{array}$ \\
\cline { 2 - 6 } Control group & & $0.1009 \pm 0.0081$ & \\
\hline $2 \mathrm{~h}$ & $0.1216 \pm 0.0099^{*}$ & $0.1222 \pm 0.0133^{*}$ & $0.1124 \pm 0.0101$ & $0.1030 \pm 0.0063$ & $0.1192 \pm 0.0076^{*}$ \\
$4 \mathrm{~h}$ & $0.1375 \pm 0.0010^{*}$ & $0.1017 \pm 0.0143$ & $0.1137 \pm 0.0157$ & $0.1224 \pm 0.0024^{*}$ & $0.1249 \pm 0.0043^{*}$ \\
$8 \mathrm{~h}$ & $0.1505 \pm 0.0122^{*}$ & $0.1284 \pm 0.0052^{*}$ & $0.1125 \pm 0.0151$ & $0.1291 \pm 0.0109^{*}$ & $0.1392 \pm 0.0040^{*}$ \\
$12 \mathrm{~h}$ & $0.1455 \pm 0.0050^{*}$ & $0.1385 \pm 0.0033^{*}$ & $0.0945 \pm 0.0136$ & $0.1285 \pm 0.0147^{*}$ & $0.1097 \pm 0.0096$ \\
$24 \mathrm{~h}$ & $0.1672 \pm 0.0483^{*}$ & $0.1216 \pm 0.0120$ & $0.1050 \pm 0.0086$ & $0.1404 \pm 0.0195^{*}$ & $0.1117 \pm 0.0043$ \\
$36 \mathrm{~h}$ & $0.1478 \pm 0.0071^{*}$ & $0.1476 \pm 0.0056^{*}$ & $0.1065 \pm 0.0052$ & $0.1543 \pm 0.0185^{*}$ & $0.1423 \pm 0.0137^{*}$ \\
$48 \mathrm{~h}$ & $0.1186 \pm 0.0139$ & $0.1128 \pm 0.0200$ & $0.1072 \pm 0.0034$ & $0.1531 \pm 0.0134^{*}$ & $0.1364 \pm 0.0061^{*}$ \\
\hline
\end{tabular}

${ }^{*} P<0.05$ when compared with control. 
APAP was combined with TRI, the reductase activity increased to $140 \%$ until $8 \mathrm{~h}$, and then it returned to the control value, but at $36 \mathrm{~h}$ and later it was elevated again.

\section{Glutathione}

All examined doses of APAP decreased GSH levels at $8 \mathrm{~h}$, but at $24 \mathrm{~h}$ they returned to the control values (Table 3). Effects of the higher doses of APAP were greater than the lowest one.

TRI decreased GSH levels as early as $2 \mathrm{~h}$ after treatment ( $68 \%$ of the control value). After- of this isoform decreased to $80 \%$ of the control value.

TRI combined with APAP had no effect on CYP1A2 at $24 \mathrm{~h}$, but after $48 \mathrm{~h}$ its level decreased to $45 \%$ of the control value.

CYP2E1 was not affected by any of the treatments studied.

\section{DISCUSSION}

TRI is an organic solvent used in industry and therefore is a common atmospheric pollutant. Metabolic processes play an essential

Table 3. Effects of different doses of acetaminophen and/or trichloroethylene on rat liver glutathione content assayed at different times after treatment.

Glutathione content is expressed in $\mathrm{mg} / \mathrm{g}$ tissue.

\begin{tabular}{cccccc}
\hline & \multicolumn{3}{c}{ Acetaminophen } & TRI & TRI + APAP \\
\cline { 2 - 5 } & $250 \mathrm{mg} / \mathrm{kg}$ & $500 \mathrm{mg} / \mathrm{kg}$ & $1000 \mathrm{mg} / \mathrm{kg}$ & $250 \mathrm{mg} / \mathrm{kg}$ & $\begin{array}{c}250 \mathrm{mg} / \mathrm{kg}+500 \\
\mathrm{mg} / \mathrm{kg}\end{array}$ \\
\cline { 2 - 5 } Control group & & $0.93 \pm 0.09$ & \\
\hline $2 \mathrm{~h}$ & $0.75 \pm 0.06^{*}$ & $0.58 \pm 0.09^{*}$ & $0.42 \pm 0.08^{*}$ & $0.63 \pm 0.07^{*}$ & $0.51 \pm 0.04^{*}$ \\
$8 \mathrm{~h}$ & $0.50 \pm 0.04^{*}$ & $0.29 \pm 0.04^{*}$ & $0.25 \pm 0.06^{*}$ & $0.76 \pm 0.08$ & $0.40 \pm 0.08^{*}$ \\
$24 \mathrm{~h}$ & $1.05 \pm 0.10$ & $1.18 \pm 0.20$ & $0.85 \pm 0.08$ & $0.82 \pm 0.08$ & $1.19 \pm 0.18$ \\
$48 \mathrm{~h}$ & $1.10 \pm 0.09$ & $1.20 \pm 0.19$ & $1.01 \pm 0.10$ & $1.03 \pm 0.12$ & $1.06 \pm 0.11$ \\
\hline
\end{tabular}

${ }^{*} P<0.05$ when compared with control.

wards, GSH level returned to the control value.

The changes caused by TRI combined with APAP were similar to those after APAP alone given at $500 \mathrm{mg} / \mathrm{kg}$.

\section{CYP1A2 and CYP2E1}

Since the most significant changes in cytochrome P450 levels were observed in rats treated with APAP at $500 \mathrm{mg} / \mathrm{kg}$ the CYP isoforms were studied only in this group of animals.

The level of CYP1A2 showed no changes at 8 $\mathrm{h}$, whereas at $24 \mathrm{~h}$ it decreased to $85 \%$ and at $48 \mathrm{~h}$ to $70 \%$ of the control value. TRI had no effect on CYP1A2 at $24 \mathrm{~h}$, but after $48 \mathrm{~h}$ the level role in triggering TRI cytotoxicity. Cytochrome P450 isoforms are key enzymes in the formation of chloral hydrate, the first product of TRI metabolism, which limits the rate of this reaction and consequently the rate of TRI metabolism. Chloral hydrate is also responsible for the hepatotoxicity and carcinogenecity of TRI.

In this study, TRI induced cytochrome P450, which was reflected by increased liver cytochrome levels. Some investigators (Koop et $a l .$, 1985) found that TRI induces CYP2E1 but it is unclear how TRI affects other cytochrome $\mathrm{P} 450$ isoforms.

In this study, TRI did not affect CYP2E1 levels, but it markedly decreased CYP1A2 levels. Both these effects contradict the noticeable in- 
crease in total cytochrome P450 content, which is our original finding. Our finding did not confirm the results of other authors (Wang et al., 1996; Hanioka et al., 1997). This increase is probably a result of induction of CYP2B1/2 (unpublished data) and CYP2C11, another constitutive P450 isoform (Wang et al., 1996). Other authors (Miller \& Guengerich, 1983; Guengerich et al., 1991; Nakaji- critical situation. Ogino (Ogino et al., 1991) and Rouisse \& Chakrabarti (Rouisse \& Chakrabarti, 1986) have shown that TRI induces lipid peroxidation in the liver and decreases the activity of NADPH-cytochrome $\mathrm{P} 450$ reductase (an enzyme that catalyzes lipid peroxidation).

High doses of APAP are hepatotoxic. APAP is converted by cytochrome $\mathrm{P} 450$ isoforms to
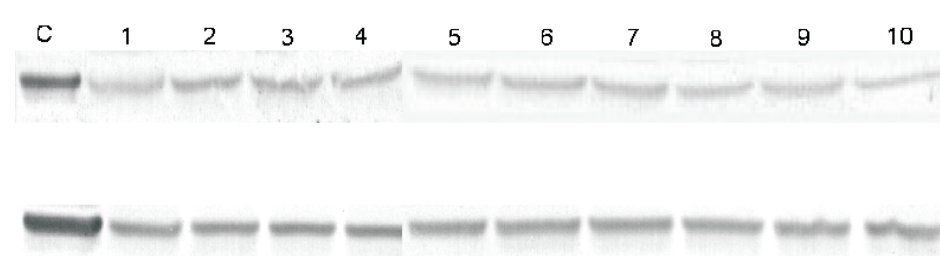

$=$
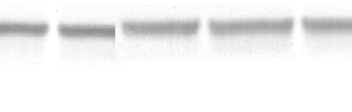

ma et al., 1992) have shown that other isoforms than reported previously are not involved in the metabolims of TRI or they play a minimal role (Wang et al., 1996).

The dose of TRI used in this study seems to produce no hepatotoxic effect. Only doses that cannot be detoxified are hepatotoxic (Rouisse \& Chakrabarti, 1986; Dekant et al., 1986). Other authors have shown that TRI-induced hepatotoxicity is maximal 22-24 h after exposure, and the pre-exposure state is restored only after 40-45 h (Okino et al., 1991; Elcombe et al., 1985). In this study, cytochrome P450 levels and NADPH-cytochrome $\mathrm{P} 450$ reductase activity remained elevated for $48 \mathrm{~h}$ since the moment of TRI administration, which indirectly indicates a lack of degenerative changes in the liver.

The animals treated with APAP and TRI combined showed a significant increase in cytochrome $\mathrm{P} 450$ levels, at $12 \mathrm{~h}$ and at $24 \mathrm{~h}$ after treatment (140\% of the control; Table 1 ), while NADPH-cytochrome $\mathrm{P} 450$ reductase activity in this groups decreased to the control value. This prolonged increase in cytochrome P450 levels seems to be an attempt to maintain the optimal activity of the cytochrome P450-dependent monooxygenase system in a
Figure 1. Effects of different doses of acetaminophen and/or trichloroethylene on rat liver CYP1A2 (top) and CYP2E1 (bottom) levels in control group (lane 1), 2 $\mathrm{h}$ (lanes 2-4), $24 \mathrm{~h}$ (lanes 5-7) and $48 \mathrm{~h}$ (lanes 8-10) after treatment APAP (500 $\mathrm{mg} / \mathrm{kg}$ ), TRI (250 mg/ kg) and APAP-TRI combination, respectively. Lane $\mathrm{C}$, standard.

$N$-acetyl-p-benzoquinone imine, a toxic compound that damages the liver unless it is bound by GSH (Nelson et al., 1990; Ryu et al., 1998). When given at a single dose of 250 $\mathrm{mg} / \mathrm{kg}$, APAP only slightly altered cytochrome P450 content (Table 1), while at 500 $\mathrm{mg} / \mathrm{kg}$ it strongly induced cytochrome P450. This shows that rats are relatively resistant to APAP (Amimoto et al., 1995). Such a high resistance (also seen at $1000 \mathrm{mg} / \mathrm{kg}$ ) results at least partially from the fact that $N$-acetyl-pbenzoquinone imine is effectively neutralized by GSH, which may be suppported by the considerable decrease in GSH levels observed at the same time (Table 3). Thus it seems that GSH is an important factor determining APAP hepatotoxicity and that GSH plays a key role in the detoxification of APAP (Kuralay et al., 1998).

Altought cytochrome P450 levels were high in the rats treated with the highest APAP dose, NADPH-cytochrome P450 activity remained unchanged despite the fact that it was induced by lower APAP doses. One can suggest that high doses of APAP result in excessive lipid peroxidation (Amimoto et al., 1995) associated with APAP-induced liver damage. This effect is independent of the hepatotoxic 
effect of APAP metabolites and therefore in this cases the protective action of GSH is ineffective.

\section{R E F E R E N C E S}

Adams, J.D., Lauterburg, B.H. \& Mitchell, J.R. (1983) Plasma glutathione and glutathione disulfide in the rat: Regulation and response to oxidative stress. J. Pharmacol. Exp. Ther. 227, 745-754.

Amimoto, T., Matsura, T., Koyama, S.-Y., Nakanishi, T., Yamada, K. \& Kaiyama, G. (1995) Acetaminophen-induced hepatic injury in mice: The role of lipid peroxidation and effects of pretreatment with coenzyme $\mathrm{Q}_{10}$ and $\alpha$-tocopherol. Free Radical Biol. Med. 19, 169-176.

Bruckner, J.V., Davis, B.D. \& Blancato, J.N. (1989) Metabolism, toxicity, and carcinogenicity of trichloroethylene. Crit. Rev. Toxicol. 20, 31-50.

Comporti, M., Maellaro, E., Del Bello, B. \& Casini, A.F. (1991) Glutathione depletion: Its effects on other antioxidant systems and hepatocellular damage. Xenobiotica 21, 1067-1076.

Corcoran, G.B. \& Wong, B.K. (1986) Role of glutathione in prevention of acetaminophen-induced hepatotoxicity by $N$-acetyl-L-cysteine in vivo: Studies with $N$-acetyl-D-cysteine in mice. J. Pharmacol. Exp. Ther. 238, 54-61.

Dahlin, D.C., Miwa, G.T., Lu, A.Y. \& Nelson, E.C. (1984) $N$-acetyl-p-benzoquinone imine: A cytochrome P450-mediated oxidation product of acetaminophen. Proc. Natl. Acad. Sci. U.S.A. 81, 1327-1331.

Dallner, G. (1974) Isolation of rough and smooth microsomes - general. Methods Enzymol. 32, 191-215.

Dekant, W., Schulz, A., Metzeler, M. \& Henschler, D. (1986) Absorption, elimination and metabolism of trichloroethylene: A quantitative comparison between rats and mice. Xenobiotica 16, 143-152.

Elcombe, C.R., Rose, M.S. \& Pratt, I.S. (1985) Biochemical, histological, and ultrastructural changes in rat and mouse liver following the administration of trichloroethylene: Possible relevance to species differences in hepatocarcinogenicity. Toxicol. Appl. Pharmacol. 79, 365-376.

Estabrook, R.W. \& Werringloer, J. (1978) The measurement of difference spectra: Application to the cytochromes of microsomes. Methods Enzymol. 52, 212-220.

Geoptar, A.R., Scheerens, H. \& Vermeulen, N.P.E. (1995) Oxygen and xenobiotics reductase activities of cytochrome P-450. Crit. Rev. Toxicol. 25, 25-65.

Guengerich, F.P. (1995) Influence of nutrients and other dietary materials on cytochrome P-450 enzymes. Am. J. Clin. Nutr. 61 (Suppl.), 651S-658S.

Guengerich, F.P., Kim, D.H. \& Iwasaki, M. (1991) Role of human cytochrome P-450IIE1 in the oxidation of many low molecular weight cancer suspects. Chem. Res. Toxicol. 4, 168-179.

Halliwell, B.\& Gutteridge, J.M.C. (1989) Protection against oxidants in biological systems: The superoxide theory of oxygen toxicity; in Free Radicals in Biology and Medicine (Halliwell, B., Gutteridge, J.M.C., eds.) pp. 86-187, Oxford University Press, New York.

Hanioka, N., Omae, E., Yoda, R., Jinno, H., Nishimura, T. \& Ando, M. (1997) Effect of trichloroethylene on cytochrome P450 enzymes in the rat liver. Bull. Environm. Contam. Toxicol. 58, 628-635.

Hodges, T.K. \& Leonard, R.T. (1974) Purification of a plasma membrane-bound adenosine triphosphatase from plant roots. Methods Enzymol., 32, 392-406.

Koop, D.R., Crump, B.L., Nordblom, G.D. \& Coon, M. (1985) Immunochemical evidence for induction of the alcohol-oxidizing cytochrome P-450 of rabbit liver microsomes by diverse agents: Ethanol, imidazole, trichloroethylene, acetone, pyrazole, and isoniazyd. Proc. Natl. Acad. Sci. U.S.A. 82, 4045-4069.

Kuralay, F., Akarca, U.S., Ozutemitz, O., Kutay, F. \& Batur, Y. (1998) Possible role of glutathione in prevention of acetaminophen-induced hepatotoxicity enhanced by fish oil in male Wistar 
rats. J. Toxicol. Environm. Health Part A 53, 223-229.

Laemmli, U.K. (1970) Cleavage of structural proteins during the assembly of the head of bacteriophage T4. Nature 227, 680-685.

Lowry, O.H., Rosebrough, N.J., Farr, A.L. \& Randal, R.J. (1951) Protein measurement with the Folin phenol reagent. J. Biol. Chem. 193, 265-275.

Miller, R.E. \& Guengerich, F.P. (1983) Metabolism of trichloroethylene in isolated hepatocytes, microsomes, and reconstituted enzyme systems containing cytochrome P-450. Cancer Res. 43, 1145-1152.

Moore, M., Thor, H., Moore, G., Nelson, S., Moldeus, P. \& Orrenius, S. (1985) The toxicity of acetaminophen and $N$-acetyl-p-benzoquinone imine in isolated hepatocytes is associated with thiol depletion and increased cytosolic $\mathrm{Ca}^{2+}$. J. Biol. Chem. 260, 13035-13040.

Nakajima, T., Wang, R.-S., Elovaara, E., Park, S.S., Gelboin, H.V. \& Vainio, H. (1992) A comparative study on the contribution of cytochrome P450 isozymes to metabolism of benzene, toluene and trichloroethylene in rat liver. Biochem. Pharmacol. 43, 251-257.

Nelson, E.B., Montes, M. \& Goldstein, M. (1990) Effectiveness of metyrapone in the treatment of acetaminophen toxicity in mice. Toxicology, 17, 73-81.

Ogino, K., Hobara, T., Kobayashi, H., Ishiyama, H., Gotoh, M., Imamura, A. \& Egami, N. (1991) Lipid peroxidation induced by trichloroethylene in rat liver. Bull. Environ. Contam. Toxicol. 3, 417-421.

Okino, T., Nakajima, T. \& Nakano, M. (1991) Morphological and biochemical analyses of trichloroethylene hepatotoxicity: Differences in ethanol- and phenobarbital-pretreated rats. Toxicol. Appl. Pharmacol. 108, 379-389.

Plewka, A. \& Kamiński, M. (1996) Influence of cholesterol and protein diet on liver cyto- chrome P-450-dependent monooxygenase system in rats. Exp. Toxic. Pathol. 47, 249-253.

Plewka, A., Kamiński, M. \& Plewka, D. (1998) Ontogenesis of hepatocyte respiration processes in relation to metabolism of xenobiotics. Mech. Ageing Develop. 105, 197-207.

Plewka, A., Bienioszek, M. \& Plewka, D. (1994) Changes in the male rat hepatic cytochrome $\mathrm{P}-450$ level, heme oxygenase and $\delta$-aminolevulinic acid synthase activities at various stages of life. Mech. Ageing Develop. 74, $79-88$.

Plewka, A. \& Bienioszek, M. (1994) Effects of age, phenobarbital, $\beta$-naphthoflavone and dexamethasone on rat hepatic heme oxygenase. Arch. Toxicol. 68, 32-36.

Rikans, L.E. \& Kasanka, S.G. (1984) Effect of aging on liver glutathione levels and hepatocellular injury from carbon tetrachloride, allyl alcohol or galactosamine. Drug Chem. Toxicol. 7, 595-604.

Rouisse, L. \& Chakrabarti, S.K. (1986) Dose-dependent metabolism of trichloroethylene and its relevance to hepatotoxicity in rats. Environm. Res. 40, 450-458.

Ryu, B.K., Ahn, B.O., Oh, T.Y., Kim, S.H., Kim, W.B. \& Lee, E.B. (1998) Studies on protective effect of DA-9601, Artemisia asiatica extract, on acetaminophen- and $\mathrm{CCl}_{4}$-induced liver damage in rats. Arch. Pharm. Res. 21, 508-513.

Tamburini, P.P. \& Schenkman, J.B. (1986) Difference in the mechanism of functional interaction betwen NADPH-cytochrome P-450 reductase an its redox partners. Mol. Pharmacol. 30, 178-185.

Wang, R.-S., Nakajima, T., Tsuruta, H. \& Honma, T. (1996) Effect of exposure to four organic solvents on hepatic cytochrome P-450 isozymes in rat. Chem.-Biol. Interact. 99, 239-252. 